\title{
Częstość występowania zespołu rozrostu bakteryjnego jelita cienkiego (SIBO) u pacjentów z cukrzycą
}

\author{
The prevalence incidence of small intestinal bacterial overgrowth (SIBO) \\ in patients with diabetes
}

\section{STRESZCZENIE}

Wstęp. Dolegliwości ze strony przewodu pokarmowego mogą występować u $50-70 \%$ osób z cukrzycą. Zespół rozrostu bakteryjnego (SIBO) to nadmierny rozplem w obrębie jelita cienkiego drobnoustrojów kolonizujących jelito grube, prowadzący do zaburzeń trawienia i wchłaniania. Celem pracy była ocena częstości występowania SIBO u pacjentów z cukrzycą, a także związek występowania SIBO z wyrównaniem metabolicznym cukrzycy i obecnością przewlekłych powikłań choroby.

Materiał i metody. Grupę badaną stanowiło 200 osób z cukrzycą (typu 1 - 91 osób; typu 2 - 109 osób), hospitalizowanych w latach 2013-2015 w Klinice Chorób Wewnętrznych i Diabetologii Uniwersytetu Medycznego im. Karola Marcinkowskiego w Poznaniu. Grupę kontrolną stanowiło 20 zdrowych ochotników. Obecność rozrostu bakteryjnego oceniano w nieinwazyjnym teście oddechowym przy użyciu urządzenia Gastro+ Gastrolyzer (firmy Bedfont) z wykorzystaniem 20 g laktulozy rozpuszczonej w $200 \mathrm{ml}$ wody, z oceną stężenia

Adres do korespondencji:

lek. Anna Adamska

Katedra i Klinika Chorób Wewnętrznych i Diabetologii

Uniwersytetu Medycznego im. Karola Marcinkowskiego w Poznaniu Szpital Miejski im. Fr. Raszei

ul. A. Mickiewicza 2, 60-0834 Poznań

Tel./faks: +48 (61) 8474579

e-mail: ania@adamska.info

Diabetologia Kliniczna 2015, tom 4, 5, 175-182

DOI: $10.5603 /$ DK.2015.0020

Nadesłano: 29.07.2015

Przyjęto do druku: 29.10.2015 wodoru w wydychanym powietrzu. Za wynik dodatni uznano zawartość wydychanego wodoru $\geq 20$ ppm (parts per milion - części na milion) lub wzrost wartości wyjściowej wydychanego wodoru o 12 ppm w czasie pierwszych 60 minut badania.

Wyniki. Występowanie SIBO w grupie badanej stwierdzono u 82 pacjentów (41\%), natomiast w grupie kontrolnej u 15 osób (75\%), p = 0,0043. Istotną różnicę stwierdzono również $\mathrm{w}$ oddzielnym porównaniu osób z cukrzycą typu 1 i 2 i z grupą kontrolną. Obecność SIBO stwierdzano istotnie częściej u osób zdrowych (75\%) niż u osób z cukrzycą typu $1(42 \%, p=0,008)$ oraz typu $2(40 \%, p=0,006)$. W modelu regresji logistycznej obecność cukrzycy wiązała się z rzadszym występowaniem SIBO niezależnie od wieku, płci i wartości BMI (OR: 0,18, 95\% Cl: 0,06-0,56; $p=0,003$ ).

Wnioski. U pacjentów z cukrzycą częstość występowania zespołu rozrostu bakteryjnego jelita cienkiego jest mniejsza niż u osób zdrowych. Jedną z możliwych przyczyn stwierdzonego związku może być korzystny wpływ leczenia żywieniowego u osób z cukrzycą. (Diabet. Klin. 2015; 4, 5: 175-182)

Słowa kluczowe: cukrzyca, zespół rozrostu bakteryjnego jelita cienkiego, powikłania jelitowe w cukrzycy, wodorowe testy oddechowe

\section{ABSTRACT}

Introduction. Gastrointestinal symptoms are present in $50-70 \%$ of patients with diabetes. Small intestinal bacterial overgrowth (SIBO) is expansion of microor- 
ganisms colonizing the large intestine into the small intestine, leading to disorders of digestion and absorption.

Material and methods. The study included 200 patients (91 with type 1 and 109 with type 2 diabetes hospitalized in years 2013-2015 in the Department of Internal Medicine and Diabetology, Poznan University of Medical Sciences. The control group consisted of 20 healthy volunteers. Hydrogen breath tests with Gastro+ Gastrolyzer (Bedfont) were used to assess SIBO. After drinking $20 \mathrm{~g}$ of lactulose we checked exhaled hydrogen concentration. The result was considered positive when exhaled hydrogen of first breath was $\geq 20$ ppm (parts per milion) or an increase in the output value of the exhaled hydrogen was $12 \mathrm{ppm}$ during the first 60 minutes of the test.

Results. We observed lower prevalence of SIBO in the test group as compared to controls [82 patients $(41 \%)$ vs. 15 patients $(75 \%) ; p=0.0043$ ]. Moreover, patients with type 1 diabetes as well as type 2 diabetes had lower incidence of SIBO as compared to controls [accordingly, $42 \%$ vs. $75 \%, p=0.008,40 \%$ vs. $75 \%$, $\mathrm{p}=0.006]$. In the logistic regression model this relationship was independent of age, gender and BMI (OR: 5,57, 95\% Cl: 1,78-17,47; $p=0,003$ ).

Conclusion. The prevalence of microbial proliferation of the small intestine in patients with diabetes is lower than in healthy subjects. One possible cause might be the beneficial effect of nutritional therapy in patients with diabetes. (Diabet. Klin. 2015; 4, 5: 175-182)

Key words: diabetes, small intestinal bacterial overgrowth (SIBO), intestinal complications, $\mathrm{H}_{2}$-breath tests, $\mathrm{H}_{2}$-BT

\section{Wstęp}

Pomimo postępu w leczeniu cukrzycy nadal u części chorych dochodzi do rozwoju przewlekłych powikłań choroby. Wydaje się, że czas trwania i kontrola metaboliczna cukrzycy mają zasadniczy wpływ na stopień zajęcia narządów. Uważa się, że w przypadku tej choroby dolegliwości ze strony przewodu pokarmowego mogą występować u 50-70\% pacjentów [1, 2]. Jedną z przyczyn może być zespół rozrostu bakteryjnego jelita cienkiego (SIBO, small intestinal bacterial overgrowth).

Jest to niejednorodny zespół, o złożonej etiologii, zdefiniowany zwiększoną ilością niepatogennych bakterii $\geq 10^{5}$ jednostek tworzących kolonie (CFU, colony forming unit) na $\mathrm{ml}$ treści jelita cienkiego. Wartość uznana za normę to $\leq 10^{4} \mathrm{CFU} / \mathrm{ml}[3,4]$. Zespół ten może przebiegać bezobjawowo lub z objawami ze stro- ny przewodu pokarmowego, które obejmują nieswoiste bóle brzucha, wzdęcia, nadmierne wytwarzanie gazów, biegunkę, utratę masy ciała $[5,6]$. Konsekwencjami SIBO w skrajnych przypadkach mogą być niedobory witamin, zaburzenia wchłaniania tłuszczów i niedożywienie [5]. Potwierdzeniem tego ostatniego może być historycznie pierwsze doniesienie z 1939 roku, w którym Barker i Hummel wysunęli hipotezę, iż przyczyną niedokrwistości makrocytarnej u chorych ze zwężeniem jelita lub zespołem jelitowym może być rozrost bakteryjny [7]. Stotzer i wsp. wykazali, że pacjenci z SIBO mają niską gęstość mineralną kości, co może być efektem zmniejszonego stężenia witaminy $25(\mathrm{OH})$ D3 (25-hydroksycholekalcyferol) oraz zjonizowanego wapnia w surowicy [8].

Mikroflora jelit człowieka jest częścią złożonego ekosystemu, regulowanego przez mechanizmy obronne gospodarza (wydzielanie kwaśnego soku żołądkowego, perystaltyka jelita, mechaniczna bariera - zastawka krętniczo-kątnicza, sekrecja immunoglobulin IgA, właściwości bakteriostatyczne żółci, wydzielanie proteolitycznych i lipolitycznych enzymów soku trzustkowego), czynniki środowiskowe i interakcje bakterii. Liczne stany mogą zaburzać tę równowagę, np. nieprawidłowości anatomiczne (np. uchyłek, zdwojenie, przetoka jelitowa, „ślepa pętla”, zwężenie jelita, chirurgiczne usunięcie zastawki krętniczo-kątniczej), zaburzenia motoryki (np. twardzina układowa i inne zapalne choroby tkanki łącznej obejmujące przewód pokarmowy, cukrzycowa neuropatia autonomiczna, enteropatia popromienna, zespół rzekomej niedrożności jelit) oraz stany sprzyjające rozplemowi bakterii (achlorhydia, długotrwałe leczenie inhibitorami pompy protonowej lub blokerami receptora $\mathrm{H} 2$, niewydolność zewnątrzwydzielnicza trzustki, wrodzone i nabyte zespoły niedoboru odporności). W większości przypadków zaangażowany jest więcej niż jeden czynnik sprawczy $[1,3,5]$.

Rozpoznanie zespołu rozrostu bakteryjnego przeprowadza się na podstawie testów inwazyjnych oraz nieinwazyjnych. Testy inwazyjne wiążą się z aspiracją treści zawartej w świetle jelita cienkiego, natomiast do testów nieinwazyjnych zalicza się m.in. wodorowe testy oddechowe (H2-BT, H2-breath tests), przy użyciu glukozy lub laktulozy $[3,4]$.

Celem pracy była ocena częstości występowania SIBO u pacjentów z cukrzycą, a także związek jego występowania z wyrównaniem metabolicznym cukrzycy i obecnością przewlekłych powikłań choroby.

\section{Materiał i metody}

Badaniem objęto 200 osób z cukrzycą (typu 1 - 91 osób, typu 2 - 109 osób) hospitalizowanych 
Tabela 1. Charakterystyka kliniczna grupy badanej i grupy kontrolnej. Wyniki przedstawiono jako mediana (IQR) lub liczba (odsetek)

\begin{tabular}{|c|c|c|c|c|c|c|c|c|}
\hline \multirow[t]{2}{*}{ Oceniane zmienne } & \multicolumn{7}{|c|}{ Grupa badana $(n=200)$} & \multirow{2}{*}{$\begin{array}{c}\text { Grupa } \\
\text { kontrolna } \\
(n=20)\end{array}$} \\
\hline & $\begin{array}{l}\text { Grupa } \\
\text { badana }\end{array}$ & $\mathbf{p}^{\#}$ & $\begin{array}{c}\text { Cukrzyca } \\
\text { typu } 1 \\
(n=91)\end{array}$ & $\mathbf{p}^{*}$ & $\begin{array}{c}\text { Cukrzyca } \\
\text { typu } 2 \\
(n=109)\end{array}$ & $\mathbf{p}^{* *}$ & $p^{\&}$ & \\
\hline Wiek (lata) & $54(44-62)$ & $<0,001$ & $45(37-54)$ & 0,014 & $59(54-64)$ & $<0,001$ & $<0,001$ & $37(29-41)$ \\
\hline Płeć K/M (n) & $70 / 130$ & 0,091 & $32 / 59$ & 0,130 & $38 / 71$ & 0,130 & 1,000 & $11 / 9$ \\
\hline Czas trwania cukrzycy (lata) & $15(10-23)$ & - & $22(14-28)$ & - & $13(8-16)$ & - & $<0,001$ & - \\
\hline Palenie tytoniu, n (\%) & $40(20)$ & 0,030 & $17(18)$ & 0,039 & $23(21,1)$ & 0,023 & 0,860 & 0 \\
\hline Nadciśnienie tętnicze, n (\%) & $142(71)$ & $<0,001$ & $45(49)$ & 0,002 & $97(88)$ & $<0,001$ & $<0,001$ & $2(10)$ \\
\hline Objawy kliniczne $(\geq 1)$ & $127(63,5)$ & 0,470 & $48(53)$ & 0,790 & $79(72)$ & 0,100 & 0,004 & $10(50)$ \\
\hline BMI $\left[\mathrm{kg} / \mathrm{m}^{2}\right]$ & $29,1(25,2-32,1)$ & $<0,001$ & $\begin{array}{c}25,0 \\
(23,3-28,8)\end{array}$ & 0,015 & $\begin{array}{c}31,3 \\
(28,8-35,4)\end{array}$ & $<0,001$ & $<0,001$ & $\begin{array}{c}23,7 \\
(20,3-24,8)\end{array}$ \\
\hline Obwód talii [cm] & $103(91-113)$ & $<0,001$ & $91(80-100)$ & 0,005 & $\begin{array}{c}110 \\
(104-117)\end{array}$ & $<0,001$ & $<0,001$ & $79(73-93)$ \\
\hline $\mathrm{HbA}_{1 \mathrm{c}}(\%)$ & $8,1(7,2-9,2)$ & - & $\begin{array}{c}7,7 \\
(7,1-8,7)\end{array}$ & - & $\begin{array}{c}8,4 \\
(7,4-9,6)\end{array}$ & - & 0,004 & - \\
\hline hsCRP [mg/l] & $1,77(0,84-3,48)$ & $<0,001$ & $\begin{array}{c}1,21 \\
(0,62-2,47)\end{array}$ & 0,025 & $\begin{array}{c}2,55 \\
(1,33-4,53)\end{array}$ & $<0,001$ & $<0,001$ & $\begin{array}{c}0,69 \\
(0,52-1,32)\end{array}$ \\
\hline TG [mmol] & $1,43(0,96-2,21)$ & 0,017 & $\begin{array}{c}0,98 \\
(0,75-1,43)\end{array}$ & 0,701 & $\begin{array}{c}1,85 \\
(1,35-2,63)\end{array}$ & $<0,001$ & $<0,001$ & $\begin{array}{c}1,11 \\
(0,91-1,36)\end{array}$ \\
\hline LDL-ch [mmol] & $2,75(2,20-3,46)$ & 0,114 & $\begin{array}{c}2,69 \\
(2,20-3,29)\end{array}$ & 0,054 & $\begin{array}{c}2,85 \\
(2,20-3,52)\end{array}$ & 0,248 & 0,189 & $\begin{array}{c}3,10 \\
(2,56-3,61)\end{array}$ \\
\hline $\mathrm{HDL}$-ch [mmol] & $1,42(1,11-1,86)$ & 0,037 & $\begin{array}{c}1,84 \\
(1,45-2,10)\end{array}$ & 0,200 & $\begin{array}{c}1,17 \\
(0,96-1,45)\end{array}$ & $<0,001$ & $<0,001$ & $\begin{array}{c}1,61 \\
(1,42-1,92)\end{array}$ \\
\hline Kreatynina [mg/dl] & $0,90(0,80-1,03)$ & 0,417 & $\begin{array}{c}0,89 \\
(0,79-1,01)\end{array}$ & 0,524 & $\begin{array}{c}0,90 \\
(0,80-1,04)\end{array}$ & 0,374 & 0,580 & $\begin{array}{c}0,90 \\
(0,80-0,93)\end{array}$ \\
\hline eGFR (MDRD) $\left[\mathrm{ml} / \mathrm{min} / \mathrm{m}^{2}\right]$ & $88(74-102)$ & 0,286 & $91(81-106)$ & 0,875 & $82(74-99)$ & 0,081 & 0,013 & $91(83-104)$ \\
\hline Neuropatia obwodowa, n (\%) & $85(42,5)$ & - & $29(32)$ & - & $56(51,4)$ & - & 0,006 & - \\
\hline Neuropatia autonomiczna, n (\%) & $29(14,5)$ & - & $9(9,9)$ & - & $20(18,3)$ & - & 0,120 & - \\
\hline
\end{tabular}

BMI (body mass index) — wskaźnik masy ciała; $\mathrm{HbA}_{1 \mathrm{c}}$ — hemoglobina glikowana; hsCRP (high-sensitive C-reactive protein) — białko C-reaktywne oznaczane metodą wysokoczułą; TG — triglicerydy; LDL-ch (low-density lipoprotein) — lipoproteiny o niskiej gęstości; HDL-ch (high-density lipoprotein) — lipoproteiny o wysokiej gęstości; eGFR (estimated glomerular filtration rate) - szacunkowy współczynnik filtracji kłębuszkowej

\#p dla porównania grup badanej i kontrolnej; *p dla porównania osób z cukrzycą typu 1 i grupy kontrolnej; **p dla porównania osób z cukrzycą typu 2

i grupy kontrolnej; \&p dla porównania osób z cukrzycą typu 1 i cukrzycą typu 2

w Klinice Chorób Wewnętrznych i Diabetologii Uniwersytetu Medycznego im. Karola Marcinkowskiego w Poznaniu w latach 2013-2015. Kryteria wykluczające z badania: wiek < 18 rż., czas trwania cukrzycy < 5 lat, przyjmowanie antybiotyków ogólnoustrojowo, inhibitorów pompy protonowej, blokerów receptora H2 w ciągu 30 dni przed badaniem. Grupę kontrolną stanowiło 20 osób bez zaburzeń gospodarki węglowodanowej. Charakterystykę kliniczną grupy badanej i kontrolnej przedstawiono w tabeli 1. Udział w badaniu był dobrowolny. Wszyscy uczestnicy wyrazili pisemną zgodę na udział w badaniu, które otrzymało zgodę lokalnej Komisji Bioetycznej.

\section{Procedura zbierania danych}

Osoby z cukrzycą oraz zdrowi ochotnicy uczestniczący w badaniu wypełnili kwestionariusz zawierający: dane demograficzne (wiek, płeć osób badanych), dane dotyczące palenia tytoniu, dane dotyczące wywiadu rodzinnego $w$ kierunku cukrzycy oraz informacje na temat chorób współistniejących i przyjmowanych leków. U wszystkich osób wykonano badanie przedmiotowe z uwzględnieniem pomiarów antropometrycznych (masa ciała, wzrost, obwód talii, obwód bioder) oraz ciśnienia tętniczego (2-krotnie metodą Korotkowa w pozycji siedzącej po 10-minutowym odpoczynku). Uczestnicy wypełnili ankietę dotyczącą dolegliwości ze 


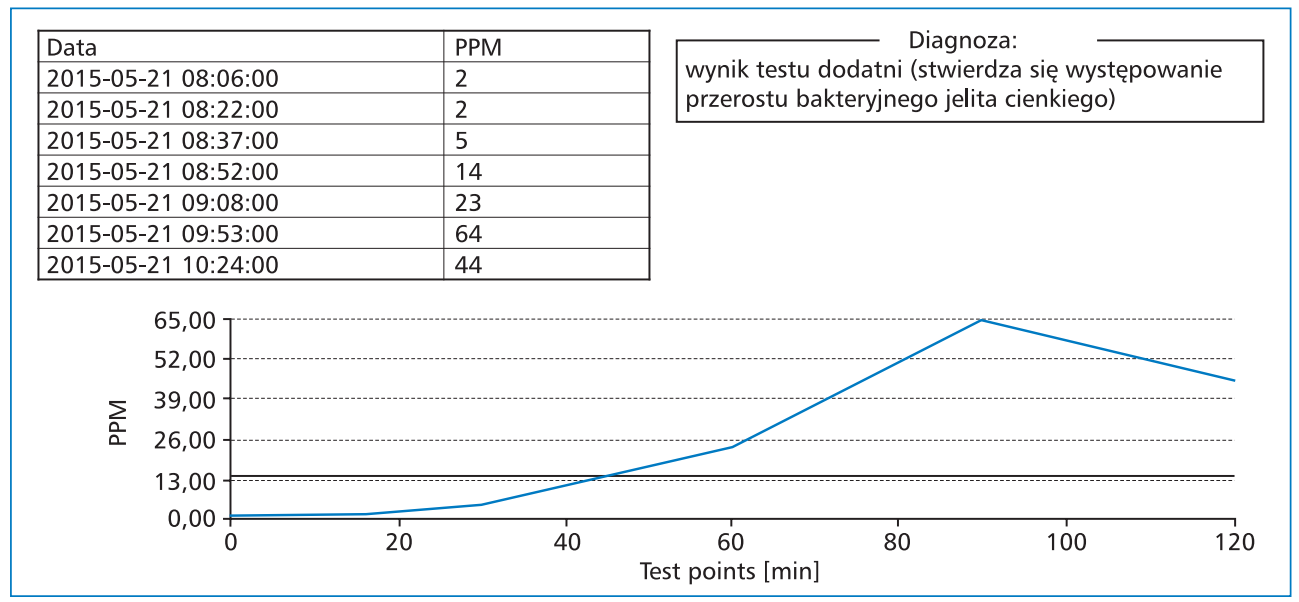

Rycina 1. Ocena występowania zespołu rozrostu bakteryjnego jelita cienkiego (SIBO) — przykładowy wynik badania

strony przewodu pokarmowego: występowanie wzdęć, odczucia oddawania nadmiernej ilości gazów, obecność dolegliwości bólowych brzucha, liczba wypróżnień w ciągu doby, obecność luźnych stolców, stolców tłuszczowych, a także informacje dotyczące utraty masy ciała, występowania zmian skórnych oraz czasu trwania objawów. Kwestionariusz dla osób z cukrzycą obejmował również dane dotyczące jej typu, czasu trwania choroby i metody leczenia.

\section{Badania laboratoryjne}

Próbki krwi pobierano na czczo, po okresie spoczynku, z minimalną okluzją żyły, w systemie Monovette. Stężenie w surowicy cholesterolu całkowitego, cholesterolu frakcji lipoprotein o dużej gęstości (HDL, high density lipoprotein), lipoprotein o małej gęstości (LDL, low density lipoprotein), triglicerydów (TG), kreatyniny mierzono za pomocą standardowych metod. Stężenie w surowicy białka C-reaktywnego (CRP, C-reactive protein) oznaczano metodą wysoce czułą. Szacowany wskaźnik filtracji kłębuszkowej został obliczony zgodnie z Modification of Diet in Renal Disease Study Group (MDRD). W grupie osób z cukrzycą oznaczono również hemoglobinę glikowaną $\left(\mathrm{HbA}_{1 \mathrm{c}}\right)$ za pomocą wysokosprawnej chromatografii cieczowej, której wartości były kalibrowane względem Diabetes Control and Complication Trial/National Glycohemoglobin Standardisation Program (DCCT/NGSP) oraz wskaźnik albumina/kreatynina w pierwszej porannej próbce moczu.

Ocena przewlekłych powikłań choroby w grupie osób z cukrzycą

Ocena neuropatii obwodowej: objawy podmiotowe oceniano na podstawie wywiadu zebranego od pacjenta. Podczas standardowego badania przedmiotowego oceniano czucie dotyku za pomocą monofilamentu, czucie wibracji za pomocą kamertonu o częstotliwości drgań $128 \mathrm{~Hz}$, czucie temperatury za pomocą TipTherm, czucie bólu za pomocą neurotipsów oraz odruchy skokowe. Neuropatię cukrzycową rozpoznawano u pacjentów z 2 lub więcej elementami z następujących 5: obecność objawów podmiotowych, zaburzenia czucia dotyku, wibracji i/lub temperatury, brak odruchów skokowych.

Ocena neuropatii autonomicznej: badanie neuropatii autonomicznej wykonano z zastosowaniem programu ProsciCard III. Badano zmienność rytmu serca w spoczynku w pozycji leżącej oraz pod wpływem określonych wystandaryzowanych bodźców (test głębokiego oddychania, próba Valsalvy, test ortostatyczny). Podczas badania na ekranie komputera monitorowano zapis EKG osoby badanej. Na podstawie obliczonych różnic odstępów R-R zostały wyliczone określone parametry do oceny neuropatii autonomicznej i porównywane z wartościami norm dla wieku i płci. Neuropatię autonomiczną rozpoznawano, jeśli wyniki 2 z 4 testów były nieprawidłowe.

\section{Ocena występowania zespołu rozrostu}

bakteryjnego jelita cienkiego (SIBO)

W grupie badanej i kontrolnej obecność SIBO oceniano w nieinwazyjnym teście oddechowym przy użyciu urządzenia Gastro+ Gastrolyzer (firmy Bedfont) z wykorzystaniem $20 \mathrm{~g}$ laktulozy rozpuszczonej w $200 \mathrm{ml}$ wody z oceną stężenia wodoru w wydychanym powietrzu. Badanie wykonywano po spoczynku nocnym, minimum 8 godzin od ostatniego posiłku (dozwolone było jedynie picie wody). Pacjenci nie palili tytoniu przez 12 godzin przed badaniem i w jego trakcie. Pomiary wykonano w 0., 15., 30., 45., 60., 90. i 120. minucie testu w pozycji siedzącej. Za dodatni wynik testu uznano wyjściową wartość wydychanego wodoru $\geq 20$ ppm (parts per milion - cząsteczki na milion) lub wzrost wartości wyjściowej wydychanego wodoru o 12 ppm 


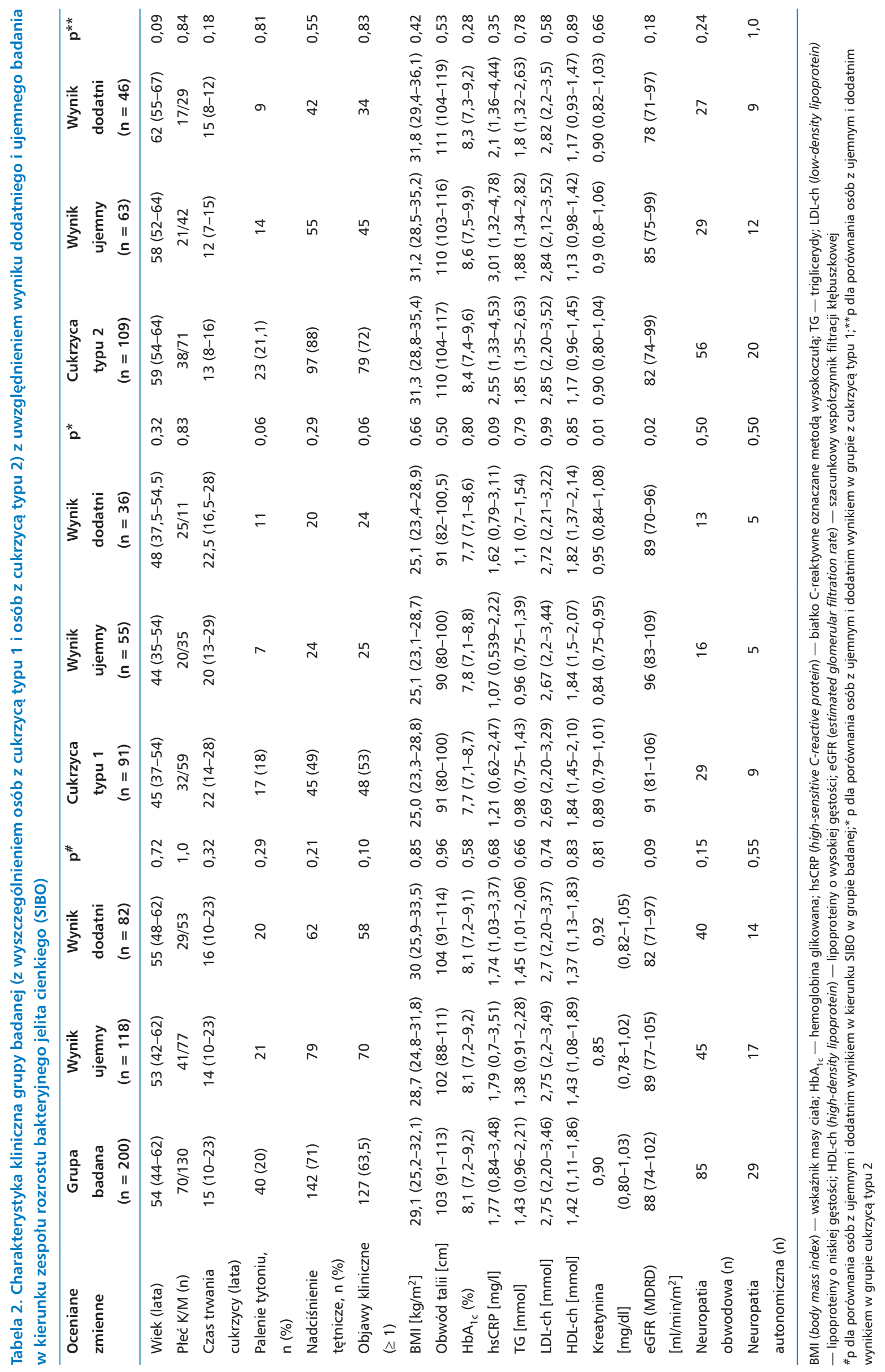


w czasie pierwszych 60 minut badania. Na rycinie 1 przedstawiono przykładowy wynik badania. W tabeli 2 porównano osoby z ujemnym wynikiem w kierunku występowania SIBO i z dodatnim wynikiem w grupie badanej oraz z wyszczególnieniem osób z cukrzycą typu 1 i z cukrzycą typu 2.

\section{Analiza statystyczna}

Otrzymane wyniki poddano ocenie statystycznej za pomocą programu komputerowego Statistica 10 (StatSoft, Tulsa, USA). Normalność rozkładów danych ilościowych oceniono z zastosowaniem testu Shapiro i Wilka. Ponieważ rozkłady znacznej większości zmiennych nie wykazywały zgodności z rozkładem normalnym, w analizach porównawczych wykorzystano test Manna-Whitneya. W przypadku zmiennych kategoralnych porównania przeprowadzono za pomocą dokładnego testu Fishera. W celu jednoczesnej oceny czynników potencjalnie związanych z obecnością SIBO wykorzystano również metodę regresji logistycznej wieloczynnikowej. Wartości zostały podane jako mediany i rozstępy międzykwartylowe lub jako liczebności i procenty [n (\%)].

\section{Wyniki}

Występowanie SIBO w grupie badanej stwierdzono u 82 pacjentów (41\%), natomiast w grupie kontrolnej u 15 osób (75\%), $p=0,0043$. Istotną różnicę wykazano również w oddzielnym porównaniu osób z cukrzycą typu 1 i 2 z grupą kontrolną. Uzyskano wynik częstości występowania SIBO odpowiednio $42 \%$ vs. $75 \%$ $(p=0,008)$ i $40 \%$ vs. $75 \%(p=0,006)$. W modelu regresji logistycznej obecność cukrzycy wiązała się z rzadszym występowaniem SIBO niezależnie od wieku, płci i wartości wskaźnika masy ciała (BMI, body mass index) (OR: 0,18, 95\% Cl: 0,06-0,56; $\mathrm{p}=0,003$ ).

Obecność cukrzycy typu 1 lub 2 wiązała się zatem z około 5-krotnie mniejszą szansą stwierdzenia SIBO.

Zbliżone wyniki uzyskano również w analogicznych modelach regresji, w których oceniano powyższy związek oddzielnie dla grupy osób z cukrzycą typu 1 (OR: 0,20,95\% Cl: 0,06-0,66; $p=0,007$ ) oraz z cukrzycą typu 2 (OR: 0,13, 95\% Cl: 0,02-0,65; $p=0,013$ ).

\section{Dyskusja}

Mikroflora jelit jest złożonym dynamicznym ekosystemem (ulega zmianie wraz z wiekiem, znacznie różni się u dzieci, osób dorosłych i w podeszłym wieku), który stanowi przedmiot badań specjalistów różnych dziedzin. Analiza jakościowa napotyka wiele trudności, m.in. ze względu na fakt, iż większości zasiedlających jelito bakterii nie można wyhodować w laboratorium, używając tradycyjnych metod i dostępnych pożywek. Możliwości identyfikacji przynoszą metody biologii mo- lekularnej [13]. Na ich podstawie ustalono, że większość wszystkich wyizolowanych drobnoustrojów należy do 4 grup bakterii: Firmicutes (64\%), Bacteroidetes (23\%), Proteobacteria (8\%) i Actinobacteria (3\%). [11] Temat charakterystyki mikroflory nie tylko przewodu pokarmowego, ale również jamy ustnej, skóry, układu moczowo-płciowego, podejmuje międzynarodowy projekt Human Microbiome Project (HMP). Jednym z najistotniejszych czynników wpływających na skład mikroflory jelitowej jest dieta. Przeprowadzone badania wykazują, że zmiana diety z nisko- na wysokotłuszczową powodowała znaczące różnice ilościowe w składzie mikroflory. Podobne wyniki uzyskali naukowcy porównujący florę bakteryjną dzieci karmionych wysokoenergetyczną dietą zachodnią oraz dzieci z regionów afrykańskich. Poza dietą mają wpływ także: genotyp, wiek, płeć oraz warunki środowiskowe. Ponadto zaobserwowano istotne różnice w składzie między mieszkańcami różnych regionów świata. Larsen i wsp. przeprowadzili badanie, w którym wzięło udział 36 kobiet (w wieku 31-72 lat), wśród których 18 cierpiało na cukrzycę typu 2. Badacze zaobserwowali zmieniony skład mikroflory jelitowej u chorych na cukrzycę typu 2 w porównaniu z pozostałymi badanymi (wykazano spadek liczebności Firmicutes i Clostridia u pacjentek z cukrzycą typu 2) [12].

Ograniczeniem pracy jest zebrana mała grupa kontrolna. Częstość występowania SIBO w populacji ogólnej nie jest znana. Częściowo wynika to z faktu, że dotychczas nie opracowano standardowego testu diagnostycznego pozwalającego na jednoznaczne rozpoznanie SIBO. Przez niektórych badaczy za „złoty standard" rozpoznania uznaje się ilościową i jakościową ocenę treści jelitowej pobranej z bliższego odcinka jelita cienkiego lub dwunastnicy zgłębnikiem wprowadzonym przez nos lub w trakcie endoskopii. Według Corazza i wsp. ocena mikroflory w aspiracie z jelita cienkiego w chromatografii gazowej lotnych kwasów tłuszczowych w porównaniu z wodorowym testem oddechowym (H2-BT) z użyciem laktulozy lub glukozy wykazała, że stwierdzenie lotnych kwasów tłuszczowych w aspiratach zawsze potwierdza SIBO $[9,10]$. Jest to jednak badanie inwazyjne i drogie, co ogranicza uzyskanie większej grupy badanej. Natomiast H2-BT jest badaniem nieinwazyjnym, łatwo dostępnym i akceptowalnym przez badanych.

Bakterie obecne w jelicie powodują fermentację laktulozy i glukozy, a w wyniku procesów zachodzących w przewodzie pokarmowym wytworzony zostaje wodór. U osób z cukrzycą zastosowanie laktulozy jest bardziej celowe, ponieważ nie powoduje wzrostu glikemii. Uzasadnieniem stosowania laktulozy w H2-BT jest praca Mendozy i wsp., w której walidacji tego testu dokonano 
przez porównanie z oceną kultur bakterii w aspiracie z dwunastnicy. Stwierdzona czułość testu H2-BT 85,7\% i swoistość 90,9\% wskazują na wysoką zgodność tych metod. Wyniki te wskazują na możliwość zastosowania H2-BT z podaniem laktulozy jako narzędzia w badaniu przesiewowym w diagnostyce SIBO [14].

W piśmiennictwie istnieje niewiele badań na temat przerostu bakteryjnego jelita cienkiego u pacjentów z cukrzycą. Dotychczas opublikowane badania przeprowadzono w mniejszych grupach pacjentów. Faria i wsp. w grupie 28 pacjentów z długotrwałą (> 10 lat) cukrzycą typu 1 nie wykazali statystycznie istotnego związku między pasażem przewodu pokarmowego a objawami żołądkowo-jelitowymi, powikłaniami cukrzycy oraz SIBO [15]. W grupie badanej w Klinice Chorób Wewnętrznych i Diabetologii stwierdzono częstość występowania SIBO u 41\% osób, w oddzielnej analizie osób z cukrzycą typu 1 u 42\% i z cukrzycą typu 2 u 40\%. Podobnie Virally-Monod i wsp. stwierdzają, że SIBO należy podejrzewać w przypadku przewlekłej biegunki u osób z cukrzycą ze względu na jego rozpowszechnienie (43\% osób z cukrzycą) [16]. W aktualnym badaniu częstość SIBO była niezależna od wartości BMI, co jest sprzeczne z wynikami badania przeprowadzonego wśród otyłych bezobjawowych pacjentów, w którym SIBO stwierdzono u $17 \%$ otyłych w porównaniu z 2,5\% u osób bez otyłości [17]. Ponadto w badaniu nie potwierdzono związku pomiędzy częstszym występowaniem SIBO a neuropatią autonomiczną (ocenianą z zastosowaniem programu ProsciCard III) [19]. Parametrem niebranym pod uwagę w badaniu była częstość przyjmowanych antybiotyków w ciągu ostatniego roku w grupie badanej. Najnowsze badania wskazują na długofalowy (nawet roczny) wpływ antybiotykoterapii zaburzający mikroflorę jelita. Rzadsze występowanie SIBO w grupie pacjentów z cukrzycą może się wiązać z częstszym stosowaniem antybiotyków w trakcie infekcji ze względu na występowanie choroby przewlekłej.

Zastosowanie odpowiedniego leczenia u pacjentów z SIBO pozwala na stałe lub czasowe ustąpienie przyczyny dolegliwości jelitowych, a co się z tym wiąże poprawę jakości życia. Zalecenia dotyczące leczenia SIBO nie są jasne, obejmują: usunięcie czynników sprawczych, suplementację witamin, podawanie probiotyków, leków prokinetycznych oraz leczenie antybiotykami. W metaanalizie 1356 artykułów najczęściej badanym antybiotykiem była ryfaksymina (8 z 10 badań, które spełniły kryteria włączenia) [19]. Według Lauritano i wsp. ryfaksymina w porównaniu z metronidazolem wykazuje większą skuteczność (mierzoną ponownym wykonaniem testów oddechowych po 1 miesiącu) oraz mniejszą częstością działań niepożądanych [20]. Furnari i wsp. wykazali, że $87 \%$ pacjentów leczonych doustnie tym antybiotykiem osiągnęło normalizację w wodorowych testach oddechowych [21]. Skuteczność probiotyku w leczeniu SIBO nie została dokładnie przebadana. W badaniu pilotażowym przeprowadzonym przez Khalighi i wsp. oceniającym skuteczność probiotyku z bakteriami kwasu mlekowego w leczeniu SIBO wykazano lepszą odpowiedź w grupie osób otrzymujących probiotyk w porównaniu z grupą kontrolną (ujemny wynik H2-BT u 93,3\% osób otrzymujących probiotyk w porównaniu z 66,7\% z grupy kontrolnej). We wszystkich przypadkach u osób otrzymujących probiotyk ból brzucha całkowicie ustąpił [22]. Dotychczas nie przeprowadzono badań analizujących wodorowe testy oddechowe po leczeniu w populacji pacjentów z cukrzycą i SIBO.

\section{Wnioski}

U pacjentów z cukrzycą częstość występowania SIBO jest niższa niż u osób zdrowych. Jedną z możliwych przyczyn stwierdzonego związku może być korzystny wpływ leczenia żywieniowego na mikroflorę jelit u osób z cukrzycą. Uzyskane wyniki nie zamykają tematu, a wręcz prowokują do dalszych badań wyjaśniających zaobserwowane zjawisko.

\section{Oświadczenie o konflikcie interesów}

Wyżej wymienieni autorzy oświadczają, że nie zachodzi żaden konflikt interesów w związku z publikowaną pracą.

Finansowanie: Grant Uniwersytetu Medycznego w Poznaniu

\section{PIŚMIENNICTWO}

1. Bures J., Cyrany J., Kohoutova D. i wsp. Small intestinal bacterial overgrowth syndrome. World J. Gastroenterol. 2010; 16: 2978-2990.

2. Krishnan B., Shithu B., Walker J. i wsp. Gastrointestinal complications of diabetes mellitus. World J. Diabetes 2013; 4: 51-63. PMCID: PMC368062.

3. Khoshini R., Dai S.C., Lezcano S. i wsp. A systematic review of diagnostic tests for small intestinal bacterial overgrowth. Dig. Dis. Sci. 2008; 53: 1443-1454.

4. Grace E., Shaw C., Whelan K. i wsp. Review article: small intestinal bacterial overgrowth - prevalence, clinical features, current and developing diagnostic tests, and treatment. Aliment. Pharmacol. Ther. 2013; 38: 674-688.

5. Saltzman J.R., Russell R.M. i wsp. Nutritional consequences of intestinal bacterial overgrowth. Compr. Ther. 1994; 20: 523-530.

6. Kirsch M. Bacterial overgrowth. Am J Gastroenterol. 1990; 85: 231-237

7. Barker W.H., Hummel L.E. Macrocytic anemia in association with intestinal strictures and anastomosis. Bull Johns Hopkins Hospital 1939; 46: 215.

8. Stotzer P.O., Johansson C., Mellstrom D. i wsp. Bone mineral density in patients with small intestinal bacterial overgrowth. Hepatogastroenterol. 2003; 50: 1415-1418.

9. Corazza G.R., Menozzi M.G., Strocchi A. i wsp. The diagnosis of small bowel bacterial overgrowth. Reliability of jejunal culture 
and inadequacy of breath hydrogen testing. Gastroenterol. 1990; 98: 302-309.

10. Gasbarrini A., Corazza G.R., Gasbarrini G. i wsp. Methodology and indications of $\mathrm{H} 2$-breath testing in gastrointestinal diseases: the Rome Consensus Conference. Aliment. Pharmacol. Ther. 2009; 29 (Supl. 1): 1-49.

11. Frank D.N., St Amand A.L., Feldman R.A., Boedeker E.C., Harpaz N., Pace N.R. Molecular-phylogenetic characterization of microbial community imbalances in human inflammatory bowel diseases. Proc. Natl. Acad. Sci. USA 2007; 104: 13780-13785.

12. Larsen N., Vogensen F.K., van den Berg F.W.J. i wsp. Gut microbiota in human adults with type 2 diabetes differs from non-diabetic adults. PLoS One 2010; 5: e9085.

13. Ludwig W., Schleifer K.H. Bacterial phylogeny based on $16 \mathrm{~S}$ and 235 rRNA sequence analysis. FEMS Microbiol. Rev. 1994; 15: 155-173.

14. Mendoza E., Crismatt C., Matos R. i wsp. Diagnosis of small intestinal bacterial overgrowth in children: the use of lactulose in the breath hydrogen test as a screening test. Biomedica 2007; 27: 325-332.

15. Faria M., Pavin E.J., Parisi M.C. i wsp. Delayed small intestinal transit in patients with long-standing type 1 diabetes mellitus: investigation of the relationships with clinical features, gastric emptying, psychological distress, and nutritional parameters. PMID: 23126582.
16. Virally-Monod M., Tielmans D., Kevorkian J.P. i wsp. Chronic diarrhoea and diabetes mellitus: prevalence of small intestinal bacterial overgrowth, Diabetes Metab. 1998; 24: 530-536.

17. Sabaté J.M., Jouët P., Harnois F. i wsp. High prevalence of small intestinal bacterial overgrowth in patients with morbid obesity: a contributor to severe hepatic steatosis. Obes. Surg. 2008; 18: 371-377.

18. Zietz B., Lock G., Straub R.H., Braun B., Schölmerich J., Palitzsch K.D. Small-bowel bacterial overgrowth in diabetic subjects is associated with cardiovascular autonomic neuropathy. Diabetes Care 2000; 23: 1200-1201.

19. Shah S.C., Day L.W., Somsouk M., Sewell J.L. Meta-analysis: antibiotic therapy for small intestinal bacterial overgrowth. Aliment. Pharmacol. Ther. 2013; 38: 925-934.

20. Lauritano E.C., Gabrielli M., Scarpellini E. i wsp. Antibiotic therapy in small intestinal bacterial overgrowth: rifaximin versus metronidazole treatment. Eur. Rev. Med. Pharmacol. Sci. 2009; 13: 111-116.

21. Furnari M., Parodi A., Gemignani L. i wsp. Clinical trial: the combination of rifaximin with partially hydrolysed guar gum is more effective than rifaximin alone in eradicating small intestinal bacterial overgrowth. Alimet. Pharmacol. Ther. 2010; 32: 1000-1006.

22. Khalighi A.R., Khalighi M.R., Behdani R. i wsp. Evaluating the efficacy of probiotic on treatment in patients with small intestinal bacterial overgrowth (SIBO) a pilot study. Indian J. Med. Res. 2014; 140: 604-608 